\title{
HISTORIA KAPLICY POD WEZWANIEM MATKI BOŻEJ NIEUSTAJĄCEJ POMOCY PRZY UL. WILCZEJ W WARSZAWIE
}

\section{Wstęp}

Warszawa jest miastem szczególnym, miastem symbolem. Jest nowoczesną metropolią, a jednocześnie wielkim pomnikiem narodowej kultury i tradycji. Miastem o bogatej przeszłości, którego historia zapisywana w wytworach kultury materialnej została prawie całkowicie zniszczona w wyniku wydarzeń II wojny światowej. Wśród wielu zabytków architektury i sztuki stolicy znajdują się budowle sakralne, ściśle wpisane w jej panoramę. Są to katedry, kościoły, kaplice, pomniki, w większości wzniesione z gruzów po zniszczeniach wojennych, tylko nieliczne bowiem ocalały z wojennej pożogi.

Jednym z takich obiektów jest kaplica pod wezwaniem Matki Bożej Nieustającej Pomocy, znajdująca się w dzielnicy Południowe Śródmieście, przy ulicy Wilczej 7. Jest to jedyny, obok Starej Pragi, ocalały fragment Warszawy wzniesiony przełomie XIX i XX wieku. O istnieniu kaplicy jednak mało kto wie. Dla potencjalnych przechodniów nie jest ona widoczna, gdyż od strony ulicy zasłania ją fasada budynków. Aby zobaczyć jej fronton, trzeba wejść w bramę domu i przejść korytarzem na wewnętrzny dziedziniec. Dzieje kaplicy są ściśle powiązane z warszawskim zakładem dobroczynnym „Przytulisko” i powstałym w nim Zgromadzeniem Sióstr Franciszkanek od Cierpiących.

\section{Początki kaplicy}

Historia kaplicy Matki Bożej Nieustającej Pomocy w Warszawie, sięga połowy XIX wieku - czasu, kiedy powstał zakład dobroczynny „Przytulisko", przeznaczony dla kobiet niemających schronienia, będących w podróży, wychodzących ze szpitali. Wraz z powołaniem do

„Nasza Przeszłość” t. 131: 2019, s. 193-216. 
życia tej instytucji, w naturalny sposób powstała również kaplica. Już od pierwszych chwil istnienia przytułku, z inicjatywy jego zarządu, osoby przebywające $\mathrm{w}$ nim były otoczone opieką duszpasterską i duchową. O tym, jak ważna to była sprawa, świadczy fakt, że główna inspiratorka i opiekunka zakładu, Franciszka Robaczewska, uzyskała od Ojca Świętego Piusa IX pozwolenie na odprawianie przez księży mszy świętych w „Przytulisku” oraz błogosławieństwo papieskie dla wszystkich, którzy w jakikolwiek sposób przyczynią się do jego rozwoju. „Dzięki tej łasce od 27 XII 1861 roku ślepe i niedołężne staruszki miały pociechę i możność słuchania codziennie Najświętszej Ofiary"."

W pierwszych latach istnienia „Przytulisko” mieściło się w wynajmowanych lokalach, które kilkakrotnie zmieniano. Konsekwencją tej sytuacji był także brak stałej kaplicy. Była tylko przenośna, pokojowa, urządzana w mieszkaniu dla ubogich, zależnie od miejsca, gdzie w danej chwili zakład się mieścił ${ }^{2}$ Sytuacja uległa zmianie w 1864 roku, gdy zarząd zakupił na cele przytułku dom przy ulicy Wilczej 7, do którego przeniesiono podopieczne.

Uzyskanie stałego lokum dla „Przytuliska” stworzyło również możliwość posiadania stałego miejsca na kaplicę. „Zacni i bogobojni Fundatorowie «Przytuliska» poczynili starania postawienia dla podopiecznych kaplicy"3. Ponieważ rząd carski rygorystycznie zwalczał wszelkie przejawy katolicyzmu na ziemiach polskich, dlatego też zarząd „Przytuliska” zamienił nazwę „kaplica” na „oficyna”. Plan budowy został zatwierdzony ${ }^{4}$. I tak, w 1864 roku zbudowano przy zakładzie pierwszą drewnianą kaplicę 5 .

\section{Powstanie kaplicy pod wezwaniem Matki Bożej Nieustającej Pomocy}

W kilka lat po wybudowaniu pierwszej kaplicy, hrabia Bronisław Skarżyński, wieloletni prezes przytułku wraz z jego fundatorami podjął starania o przebudowę kaplicy drewnianej na murowaną. Budowę

\footnotetext{
${ }^{1}$ Archiwum Zgromadzenia Sióstr Franciszkanek od Cierpiących w Warszawie (dalej: AFC), sygn. E I, T. I-Kr/3, Kronika kaplicy Przytuliska, s. 1.

${ }^{2}$ Zob. AFC, sygn. C I, T. II-MK/67 H. W ł a d z i ń s k a, Wspomnienia, s. 50.

${ }^{3}$ AFC, sygn. E I, T. I-Kr/3, Kronika kaplicy, s. 1.

${ }^{4}$ Zob. tamże, s. 1-2.

${ }^{5}$ Zob. AFC, sygn. D I, T. VI-Przyt/15, Kaplica Instytutu Dobroczynnego przy ulicy Wilczej 7, s. 7.
} 
nowej świątyni ukończono w 1870 roku i 11 grudnia tegoż roku Administrator Archidiecezji Warszawskiej, ksiądz prałat Stanisław Zwoliński, dokonał poświęcenia kaplicy pod wezwaniem Matki Bożej Nieustającej Pomocy. Na tej uroczystości kazanie wygłosił ksiądz Kazimierz Ruszkiewicz 6 .

Jak wynika z zapisów archiwalnych, kaplica „Przytuliska” stała się miejscem modlitwy nie tylko dla mieszkanek zakładu. Korzystała z niej także okoliczna ludność. W Kronice kaplicy znajduje się zapis: „Kościół parafialny św. Aleksandra był zbyt szczupły, by pomieścić wiernych. Toteż kapliczka, choć mała, okazała się wielce użyteczną i bardzo licznie uczęszczaną"7. Niebawem okazało się, że nie tylko kościół, ale także kaplica nie zawsze mogła pomieścić tych, którzy do niej uczęszczali. Aby temu zaradzić, powiększono jej powierzchnię, włączając w nią zakrystię. $\mathrm{Na}$ zakrystię natomiast przeznaczono mieszkanie księdza kapelana ${ }^{8}$.

Wobec takiej sytuacji trudno było ukryć, że w „Przytulisku” znajduje się kaplica. Ponieważ nie było urzędowego pozwolenia na jej powstanie, władze policyjne zakwestionowały prawo do istnienia świątyni. Jednak dzięki osobistej interwencji hrabiego Bronisława Skarżyńskiego u generał-gubernatora, hrabiego Pawła Kotzebuego, tolerowano jej istnienie, ale z zastrzeżeniem, że jest to kaplica prywatna?.

\section{Przebudowa kaplicy}

W 1911 roku zakończono konieczną rozbudowę i modernizację zakładu "Przytulisko" ". Jak się okazało, budynek kaplicy również wymagał remontu. Wówczas, z inicjatywy przełożonej „Przytuliska”, Matki Kazimiery Gruszczyńskiej, mimo obaw o brak możliwości sfinansowania tej inwestycji, podjęto decyzję o budowie nowej, więk-

\footnotetext{
${ }^{6}$ Zob. AFC, sygn. E I, T. I-Kr/1, Pierwsza Księga Kroniki Zgromadzenia Sióstr Franciszkanek od Cierpiących prowadzona w Domu Głównym w Warszawie od 1946 roku, s. 111.

${ }^{7}$ AFC, sygn. E I, T. I-Kr/3, Kronika kaplicy, s. 2.

${ }^{8}$ Zob. tamże.

${ }^{9}$ Zob. tamże.

${ }^{10}$ Od 1882 roku w „Przytulisku” istniało ukryte zgromadzenie, powstałe z inicjatywy o. Honorata Koźmińskiego, założone przez Kazimierę Gruszczyńską. W związku z koniecznością przystosowania przytułku, w którym mieścił się macierzysty dom Zgromadzenia Sióstr Franciszkanek od Cierpiących do potrzeb mieszkających w nim sióstr, w latach 1910-1911 dokonano koniecznej rozbudowy „Przytuliska”.
} 
szej kaplicy na miejscu dotychczasowej. Matka Kazimiera w Historii Zgromadzenia Sióstr Franciszkanek od Cierpiacych zamieściła zapis: „Dom mieszkalny przebudowany, ale tu nie koniec budowy. Pozostała jeszcze ubożuchna kapliczka w pierwotnym zarysie, którą grzyb mimo ciągłych zabiegów stale niszczył. Było niepodobieństwem, aby przybytek Boży pozostawiać w tych warunkach. Nie było innej rady, jak tylko do ostatniej cegły $\mathrm{z}$ fundamentu rozebrać, wszystko wywieźć, żeby zarazka grzyba nie zostawić, a natomiast $\mathrm{z}$ gruntu postawić nową kaplicę. Zarząd uznał potrzebę, ale przy najszczerszych chęciach, nie posiadając żadnych funduszów, tylko zaciągnięte długi na budowę Zakładu - stanowczo na to się nie zgodził, ale w łaskawości swej nie przeszkadzał Zgromadzeniu, które, ufając pomocy Bożej, szczerze się zakrzątnęło, aby tę świątyńkę zbudować" ". Niezwłocznie przystąpiono do zrobienia projektu budowy. Ze względu na umiejscowienie kaplicy wewnątrz istniejących zabudowań oraz dysponując stosunkowo niewielkim placem pod budowę, wykonanie odpowiedniego planu okazało się rzeczą trudną. Ostatecznie, po wielu odrzuconych propozycjach, Wiktor Junosza Piotrowski, Budowniczy Gubernialny, który zajmował się przebudową „Przytuliska”, za zgodą Matki Kazimiery i zarządu przytułku, zaprosił do współpracy inżyniera Konstantego Sylwina Jakimowicza. Stworzony przez niego projekt jednogłośnie przyjęto przez komitet przytułku ${ }^{12}$.

Odpowiedzialnym za budowę nowej kaplicy został Wacław Wędrowski. W Aktach budowy kaplicy znajduje się umowa zawarta przed rozpoczęciem prac, pomiędzy Walerianem Strzałkowskim, działającym z upoważnienia zarządu „Przytuliska” a Wacławem Wędrowskim, wykonawcą budowy. Według umowy, W. Wędrowski zobowiązał się do przeprowadzenia prac budowlanych, objętych kosztorysem i projektem wykonanym przez architekta Konstantyna Jakimowicza. Umowa zatwierdzona została przez Warszawski Rząd Gubernialny w dniu 27 lipca 1912 roku, Nr 1061. Ryczałt umówionej sumy wynosił: 7211 rubli 80 kopiejek $^{13}$. Jak wynika z treści umowy, zakończenie budowy powinno nastąpić najpóźniej 15 października 1913 roku.

${ }^{11}$ K. G r u s z c z y ń s k a, Historia Zgromadzenia SS. Franciszkanek od Cierpiacych, oprac. L. Czermińska, J. Marecki, Kraków 2019, s. 111.

${ }^{12}$ Zob. tamże.

${ }^{13}$ Zob. AFC, sygn. D I, T. VII-Przyt/30, Akta Budowy Kaplicy w Przytulisku w Warszawie 1913. 
W razie opóźnienia w terminach, zarząd „Przytuliska” miał prawo potrącenia 25 rubli za każdy dzień zwłoki.

Wypłata miała być uskuteczniana w miarę postępu prac:

- po doprowadzeniu budowy do parapetu okna: 1000 rubli

- po doprowadzeniu prac żelazo-betonowych: 1500 rubli

- po pokryciu dachu: 1500 rubli

- po wewnętrznym wytynkowaniu i obsadzeniu okien żelaznych: 1000 rubli.

Natomiast reszta należności miała być wypłacona po ostatecznym zakończeniu prac i przyjęciu robót z zatrzymaniem 2,5\% całkowitej należności tytułem rocznej gwarancji. Głównym nadzorcą prac budowlanych został architekt Konstantyn Jakimowicz, którego kontroli podlegał również materiał budowlany. W umowie zastrzeżono: „W razie przerwania robót $\mathrm{z}$ winy $\mathrm{p}$. Wędrowskiego lub nie stosowania się do wskazówek prowadzącego budowę Architekta, Zarządowi przysługuje prawo powierzyć dalsze prowadzenie robót innej firmie, potrącając straty stąd wynikłe z należności przypadającej p. Wędrowskiemu"14. Umowa została sporządzona w dwóch jednobrzmiących egzemplarzach, z których jeden otrzymał wykonawca budowy, a drugi - zarząd „Przytuliska”. Pod umową widnieje data 17 maja 1913 roku oraz własnoręczny podpis Wacława Wędrowskiego ${ }^{15}$.

Po załatwieniu powyższych formalności rozpoczęto prace budowlane. Jak wspomina Kazimiera Gruszczyńska, „dnia 17 maja 1913 zaczęto pierwszy rzut ziemi szpadlem dla położenia kilku cegiełek przez domowników i dzieci budowniczego, zaś 9 czerwca tegoż roku, założenie kamienia węgielnego" 16 . Wmurowania aktu erekcyjnego i poświęcenia fundamentów pod nową kaplicę dokonał ksiądz biskup Kazimierz Ruszkiewicz dnia 9 czerwca 1913 roku $^{17}$. W Archiwum Zgromadzenia Sióstr Franciszkanek od Cierpiących zachowała się Kopia aktu poświęcenia $i$ złożenia kamienia węgielnego pod nowa kaplicę Przytuliska. Jest to rękopis hrabiego Feliksa Grabowskiego, prezesa zakładu. Na podstawie tego dokumentu można dokładnie odtworzyć owo wy-

\footnotetext{
${ }^{14}$ Zob. tamże.

${ }^{15}$ Zob. tamże.

${ }^{16}$ K. G r u s z c z y ń s k a, Historia Zgromadzenia, s. 111.

${ }^{17}$ Zob. AFC, sygn. D I, T. VI-Przyt/9, Z chwili poświęcenia kamienia węgielnego pod kaplicę Przytuliska, s. 3.
} 
darzenie, które „Działo się w Warszawie. Roku Pańskiego tysiącznego dziewięćsetnego trzynastego, miesiąca czerwca dnia dziewiątego w poniedziałek po Niedzieli czwartej po zielonych świątkach [...] w godzinie czwartej po południu, za Rządów [...] Namiestnika Chrystusowego Papieża Piusa Dziesiątego" "18. Oryginał aktu erekcyjnego napisany został tuszem, na pergaminie. Podpisała go większość osób duchownych i świeckich obecnych podczas uroczystości. Poniżej podpisów naklejona została kartka $\mathrm{z}$ nadesłanym błogosławieństwem o. Honorata Koźmińskiego, który własnoręcznie napisał: „Boże błogosław”. Dokument umieszczono w szklanym słoju razem z oryginałem opisu przeniesienia Najświętszego Sakramentu do prowizorycznej kapliczki, utworzonej na czas budowy ${ }^{19}$. Do słoja włożono także dwadzieścia sztuk medalików, jeden medal brązowy z XXV roku pontyfikatu papieża Leona XIII, dwie monety - dwuzłotówkę polską z 1831 roku i grosz polski z 1776 roku, cztery dzienniki, które ukazały się tego dnia, tj. „Gazeta Poranna 2 Grosze”, „Kurier Ilustrowany”, „Kurier Poranny”, „Polak - Katolik”. Słój, hermetycznie zamknięty korkiem, umieszczono w glinianym garnku i szczelnie zawinięto płócienną matą. Wszystko razem wstawiono do wycementowanego okrągłego otworu w narożniku prezbiterium. Na nim ksiądz biskup Kazimierz Ruszkiewicz umieścił kamień węgielny z szarego marmuru, po czym całość zamurowano ${ }^{20}$.

Wydarzenie związane z wmurowaniem kamienia węgielnego pod nową kaplicę „Przytuliska” odbiło się szerokim echem w społeczeństwie Warszawy. W „Kurierze Warszawskim”, który ukazał się następnego dnia w stolicy, można było przeczytać: „Wczoraj w godzinach popołudniowych J. E. ks. bp Kazimierz Ruszkiewicz, administrator archidiecezji warszawskiej w asystencji kilku kapłanów, poświęcił kamień węgielny pod nowobudowaną kaplicę «Przytuliska» przy ulicy Wilczej 7. W uroczystości tej uczestniczyli członkowie zarządu, ubogie staruszki wraz z personelem zakładu, lekarze zakładowi, dd-rowie Chrostowski, Kilzner i Sierpiński, budowniczowie Piotrowski i Jakimowicz oraz zajęci przy nowej budowie rzemieślnicy i robotnicy,

\footnotetext{
${ }^{18}$ Tamże.

19 Przeniesienie Najświętszego Sakramentu do tymczasowej kaplicy na czas trwania budowy odbyło się 27 IV 1913 roku. Zob. AFC, sygn. D I, T. VI-Przyt/9, Z chwili poświęcenia, s. 1.

${ }^{20}$ Zob. tamże.
} 
tudzież kilka osób, życzliwych «Przytulisku»"21. Podobną treść podała „Gazeta Warszawska”, „Słowo”, „Polak - Katolik”, „Gazeta Poranna 2 Grosze” i „Przegląd Katolicki”.

Budowa kaplicy przypadła w nader trudnych warunkach, które przyniosła I wojna światowa. Nie zgasiło to jednak zapału Inicjatorki dzieła ani jego wykonawców. We wspomnianej Historii Zgromadzenia pisanej przez Matkę Kazimierę, widnieje zapis: „W następnym roku zaczętej budowy, tj. w 1914, wybuchła wszechświatowa wojna. Mimo trudności, robót nie przerwaliśmy. Pracownicy oceniali, że mają zajęcie; z naszej strony usiłowania, aby jak najprędzej doprowadzić do zakończenia tej budowy" 22 . Ponadto, Konstanty Jakimowicz, będąc w Rzymie w 1914 roku, uzyskał od papieża Piusa X błogosławieństwo na budowę kaplicy i odpust na uroczystość św. Józefa. Fakt ten jeszcze bardziej pobudzał do zaufania opatrzności Bożej i kontynuowania prac ${ }^{23}$.

W 1915 roku nadszedł dzień ukończenia budowy. Zaczęto przygotowania do uroczystości poświęcenia nowej kaplicy. Z prośbą o dokonanie tego aktu zwrócono się do księdza biskupa Kazimierza Ruszkiewicza, który zaproszenie przyjął i obiecał przewodniczyć ceremonii. Na kilka dni przed uroczystością ksiądz kanonik Stanisław Gall, późniejszy biskup polowy, oraz ksiądz Aleksander Fajęcki zostali wydelegowani przez kurię warszawską, aby sprawdzić, czy wybudowana kaplica oraz jej wyposażenie spełniają wymagane warunki dla dokonania poświęcenia. Odpowiedź, jaką po tej wizytacji otrzymała Matka Kazimiera, zaskoczyła wszystkich. W Historii Zgromadzenia Matka odnotowała: „Po obejrzeniu budowy przez przedstawicieli Władzy Duchownej, nie tylko ołtarz, ale cała kaplica swą budową kwalifikuje się do konsekracji ${ }^{24}$ jako kościół. [...] Trudno mi było uwierzyć tak wielkiemu szczęściu”"25.

Po otrzymaniu tej radosnej informacji zaczęto ostatnie przygotowania do poświęcenia kaplicy. Uzupełniono konieczne wyposażenie i sprzęty. Sam dzień uroczystości zapadł głęboko w pamięci wszystkich. „Ceremonia naznaczona na dzień 18 III 1915 r. W wigilię śnieg

21 „Kurier Warszawski”, 10 czerwca 1913, nr 158, s. 5.

${ }^{22}$ K. G r u s z c z y ń s k a, Historia Zgromadzenia, s. 111.

${ }^{23}$ Zob. AFC, sygn. E I, T. I-Kr/3, Kronika kaplicy, s. 3.

${ }^{24}$ Obecnie termin ,konsekracja” odnosi się tylko do osób; budynki sakralne są najpierw błogosławione, następnie poświęcane przez biskupa (dawny obrzęd konsekracji).

${ }^{25}$ AFC, K. G r u s z c z y ń s k a, Historia Zgromadzenia, s. 112. 
z deszczem, ziąb, w całej sile wichura marcowa, słowem nieodpowiednia pora na obrzęd konsekracji kościoła. [...] Nazajutrz wczesnym rankiem przybył J. E. Ks. Arcybiskup Ruszkiewicz w otoczeniu Duchowieństwa rozpoczął Ceremonie. Tej uroczystej chwili opisywać nie będę - jest to Ceremoniał jeden chyba z najdłuższych w Kościele - od godziny $7 \frac{1}{2}$ - trwało blisko południa” ${ }^{26}$. „Po skończeniu Najświętszej Ofiary [ks. bp Ruszkiewicz] ochrzcił dzwon z następną dedykacją: «Imię moje JÓZEF KAZIMIERZ w czasie wielkiej wojny zacząłem głosić Chwałę Bożą» ${ }^{27}$. [...] Kościółek całkowicie zbudowany kosztem Zgromadzenia"28 - dopisała Kazimiera Gruszczyńska na zakończenie relacji.

Na podstawie zachowanej dokumentacji można dokładnie prześledzić, jak wyglądała sprawa sfinansowania budowy. Jak wspomniano, Matka Kazimiera zobowiązała się do wystarania się o zdobycie funduszy na budowę kaplicy. Sama też prowadziła rachunki budowlane. W archiwum znajduje się księga Rachunków kaplicy Przytuliska (dochody i rozchody)", w której koszt budowy obliczony jest bardzo dokładnie: „Koszta budowy tegoż Kościółka tj. rb. 16686 kop. 78 pokryte zostały z osobistych ofiar członkiń Towarzystwa Pielęgnowania Chorych pod wezwaniem św. Józefa. Warszawa dnia 9 maja 1917 r. [podpisała] Kazimiera Gruszczyńska"29. Należy wyjaśnić, że członkinie Towarzystwa Pielęgnowania Chorych były jednocześnie członkiniami Zgromadzenia Sióstr Franciszkanek od Cierpiących. Podejmowały prace w szpitalach, w zakładach, w domach prywatnych, a wynagrodzenie za pracę wnosiły do wspólnej kasy. Ponadto niektóre z nich, wstępując do zgromadzenia wnosiły posag, który był zasileniem budżetu Zgromadzenia tożsamego z Towarzystwem. Stąd, dzięki tym dochodom możliwe było regulowanie koniecznych płatności, a także spłacanie zaciągniętych na poczet budowy pożyczek, gdyż na pokrycie bieżących rachunków, Matka zaciągnęła pożyczki, najpierw w Banku Handlowym, a następnie w Towarzystwie Kredytowym Miasta Warszawy.

Pomocy materialnej udzielały jej także środowiska warszawskiej arystokracji. W księdze Rachunków kaplicy Przytuliska, w rubryce do-

\footnotetext{
${ }^{26}$ Tamże, s. 112-113.

${ }^{27}$ AFC, sygn. D I, T. VI-Przyt/8, Dokumenty konsekracji kaplicy i dzwonu.

${ }^{28}$ K. G r u s z c z y ń s k a, Historia Zgromadzenia, s. 113.

${ }^{29}$ AFC, sygn. D I, T. VII-Przyt/28, Rachunki kaplicy Przytuliska [dochody i rozchody].
} 
chodów, wśród ofiarodawców w latach 1912-1915 wyszczególnieni są: „Hr. Władysław Branicki, hr. Aleksandra Potocka, hr. Grabowski, hr. Zofia Grabowska, hr. Zamoyska Zdzisławowa, ks. Radziwilłowa Karołowa, ks. Prałat Brzeziewicz, ks. Kanonik Pleszczyński, ks. Prałat Łyszkowski, baronowa Zachert, mecenas Strzałkowski, p. Rostkowski, p. Gawrońska, Baccarelli Kazimierzowa"30. W dokumentacji zachowały się także listy pisane przez Kazimierę Gruszczyńską z prośbą o udzielenie pomocy materialnej oraz podziękowania za otrzymaną hojność serca, kierowane do zamożnych, arystokratycznych rodzin, znanych $\mathrm{z}$ działalności filantropijnej. Uzyskana w ten sposób pomoc materialna, w znacznym stopniu pozwalała na szybkie prowadzenie rozpoczętych prac przy budowie kaplicy ${ }^{31}$.

\section{Okres II wojny światowej}

Jak już wspomniano, kaplica Matki Bożej Nieustającej Pomocy przez cały czas istnienia służyła nie tylko podopiecznym "Przytuliska” i Zgromadzeniu Sióstr Franciszkanek od Cierpiących, ale także okolicznej ludności. Tutaj odbywały się śluby, jubileusze, msze święte prymicyjne, w niej gromadzono się w święta, uroczystości, również wiele osób przychodziło na prywatną modlitwę w różnych porach dnia.

Nową kartę historii kaplicy otwiera trudny okres II wojny światowej. W chwili jej rozpoczęcia kaplica przy ulicy Wilczej 7 obudowana była dwiema sześciopiętrowymi kamienicami od ulicy Wilczej 5 i Mokotowskiej 61. W czasie nalotów 25 września 1939 roku w tych domach wybuchł pożar, który trwał trzy doby. Ogień rozprzestrzeniał się także wokół kaplicy i zakrystii. Siostry z narażeniem życia tłumiły ogień i nie dopuściły, aby płomienie zajęły kaplicę. W niedługim czasie, na kamienicę przylegającą do kaplicy od strony ulicy Wilczej zrzucono bombę. Walący się gruz zniszczył całkowicie dach wraz z krokwiami, tynki w 50\% odpadły z elewacji, wypadły wszystkie szyby, na ścianach pojawiły się rysy. Ocalenie kaplicy we wrześniu 1939 roku przypisano opiece Bożej i przemożnemu orędownictwu Matki Bożej Nieustającej Pomocy. Opis tego cudu opatrzności Bożej znajduje się w Kronice kaplicy, gdzie zanotowano: „Podczas oblężenia Warszawy, gdy płonęły kamienice przylegające do kaplicy w 1939 roku, a wody nie było do gasze-

\footnotetext{
${ }^{30}$ Tamże.

${ }^{31}$ Zob. tamże.
} 
nia, ni straży pożarnej, jakiś mężczyzna przyszedł o zmroku do kaplicy i padł krzyżem na posadzkę pokrytą gruzem i szkłem i głośno swymi słowami modlił się: «Panie, nie zatracaj tego domu, którego mieszkanki pełnią tyle miłosiernych uczynków». Wszyscy będący świadkami grozy niebezpieczeństwa uznali za cudowne, że świątynia i zakład nie spłonęły w morzu otaczających płomieni. Ponieważ pożar trwał 3 doby, milicja zarządziła ewakuację «Przytuliska». Zakrystianka usunęła z zakrystii paramenty, a siostra Marta Sawukinas wyjęła z ołtarza Cudowny Obraz Matki Boskiej Nieust. Pomocy i umieściła go w oratorium. W lęku i grozie głośno zawołała: «Matko Boska ratuj nas!». Obecni podchwycili i powtarzali bez końca ten akt. Gdy niebezpieczeństwo pożaru kaplicy minęło, ludzie uznali, że Matka Najśw. na wołanie pełne ufności pośpieszyła z cudowną swą pomocą"32. Po kapitulacji Warszawy dokonano prowizorycznych napraw. Aby zabezpieczyć budynek, dach pokryto papą, szyby w znacznej części zastąpiono dyktą ${ }^{33}$. Kolejnych zniszczeń doznała kaplica w 1944 roku, w czasie powstania warszawskiego. Na brzeg ściany spadł szrapnel, po czym zsunął się po murze. Ściana została w dużej mierze zrujnowana, a brama i drzwi mocno uszkodzone. Jednakże kaplica uniknęła całkowitego zniszczenia ${ }^{34}$.

W okresie okupacji kaplica była zawsze otwarta. Szczególnie w czasie powstania warszawskiego gromadziła ogromne rzesze mieszkańców stolicy. Przychodziło do niej dużo ludzi, aby skorzystać z sakramentów świętych: spowiedzi i Komunii Świętej. W czasie nasilonych walk ksiądz kapelan Antoni Kwieciński kilkakrotnie udzielał ogólnego rozgrzeszenia. Siostra Barbara Czerwińska, która podczas powstania prowadziła notatki, wspomina, że w kaplicy odprawiało się po kilka mszy św. dziennie. Pod datą 7 sierpnia 1944 roku zanotowała: „Mszy św. było kilka, kaplica przepełniona ludźmi. Garną się do spowiedzi i Komunii św. Ksiądz kapelan całymi dniami spowiada"35. Natomiast siostra Małgorzata Grajewska w swoim dzienniku w dniu 26 sierpnia 1944 roku zapisała: „U nas w kaplicy codziennie wysta-

\footnotetext{
${ }^{32}$ AFC, sygn. E I, T. I-Kr/3, Kronika kaplicy, s. 14-15.

${ }^{33}$ Zob. tamże, s. 4-5.

${ }^{34}$ Zob. tamże, s. 5.

35 AFC, sygn. E I, T. I-oD/3, B. C ze rwińs k a, Powstanie sierpniowe 1944 r. warszawskie notatki Barbary Czerwińskiej 1 VIII-30 IX 1944 r.
} 
wienie Przenajświętszego Sakramentu. Tłumy ludzi przystępują do Komunii św. Przez cały dzień kaplica przepełniona"36.

W czasie wojny w stolicy panowała żałoba. Główne place i skwery Śródmieścia zamieniły się w cmentarze. W niedalekiej odległości od kaplicy, na placu Trzech Krzyży oraz na skwerze przy ulicy Frascati grzebano zmarłych - były to dwa największe cmentarze w Śródmieściu Południowym. We wrześniu 1944 roku zbombardowany został kościół św. Aleksandra na placu Trzech Krzyży. Walący się ze stropów i ścian gruz zniszczył tabernakulum i rozbił puszki z Najświętszym Sakramentem. Odkopane z gruzów konsekrowane Hostie przeniesiono do kaplicy na ulicę Wilczą. Tutaj wyjęto je z rozbitych puszek i oczyszczono z kurzu.

W przekonaniu świadków, bezgraniczne zawierzenie Bożemu miłosierdziu przez wszystkich skupionych wokół „Przytuliska” i kaplicy Matki Bożej Nieustającej Pomocy, uratowało ją od całkowitego zniszczenia. Jerzy Ekner, opisując uratowanie kaplicy przy ulicy Wilczej 7 od zniszczeń wojennych, pisze: „Dane mi było przeżyć 33 dni Powstania na Starym Mieście i dlatego wiem, co oznacza gwizd kuli niosącej śmierć, huk i trzęsienie ziemi po wybuchu bomby i pocisku artyleryjskiego, odczułem gorąco płonącego domu, którego nie było możliwości gasić, aż spłonął do fundamentów. Dlatego mogę powtórzyć, że kaplica [Matki Bożej Nieustającej Pomocy przy ul. Wilczej w Warszawie] zbudowana 100 lat temu ma przywilej trwałości i uratowała ludzi szukających schronienia",37.

Pomimo działań wojennych, panującego lęku przed niewiadomą przyszłością i przed śmiercią, w kaplicy Matki Bożej Nieustającej Pomocy przy ulicy Wilczej, miały miejsce również radosne i uroczyste wydarzenia. Jednym z nich był ślub kuriera i łączniczki. Otóż, 7 września 1944 roku, w kaplicy odbył się ślub Zdzisława Jeziorańskiego, ps. Jan Nowak, i Jadwigi Wolskiej, ps. Greta. Po latach „Kurier z Warszawy” [Jan Nowak-Jeziorański] tak wspominał ten dzień: „Kaplica była pełna. Niemcy siedzieli o trzysta metrów dalej w Alejach Ujazdowskich. Szliśmy do ołtarza po podłodze zasłanej potłuczonym szkłem, które łamało się z trzaskiem pod nogami. W oknach kaplicy nie pozostał ani jeden

\footnotetext{
${ }^{36}$ AFC, sygn. E I, T. I-oD/34, M. Grajewska, Fragmenty przeżyć i myśli z powstania 1944 r. - dziennik Małgorzaty Grajewskiej prowadzony od 1 VIII - 1 IX 1944 r.

${ }^{37}$ J. E k n e r, KAPLICA p. w. Matki Bożej Nieustającej Pomocy [Artykuł w zbiorach prywatnych Autora], s. 2.
} 
witraż. Ksiądz spieszył się na pogrzeb i ceremonia nie trwała dłużej niż siedem minut. Delegacja «Chwatów» w osobach dwóch młodziutkich żołnierzy wręczyła «Grecie» wiązankę gladiolusów zerwanych w ogrodach zakładu Głuchoniemych i Ociemniałych"38. W zrujnowanej kaplicy nowożeńcy powiedzieli sakramentalne tak na przekór wszechobecnej śmierci; myśleli, że na dwa tygodnie, a przeżyli razem 55 lat ${ }^{39}$.

Po upadku powstania, w czasie ewakuacji Warszawy siostry franciszkanki od cierpiących musiały opuścić „Przytulisko”. Kaplica została zamknięta. Zniszczona, pozbawiona dachu i szyb okiennych, stanowiła skład różnych rzeczy, pozostawionych przez ewakuowanych ludzi po powstaniu warszawskim. Przed wyjazdem z Warszawy siostry zabrały ze sobą jedynie ważne dokumenty oraz szaty i naczynia liturgiczne oraz najcenniejsze rzeczy. Część ornatów codziennych wraz z monstrancją zamurowały w piwnicy. Były tam piękne hafty richelieu wykonane przez Matkę Kazimierę Gruszczyńską i przez pierwsze siostry ze Zgromadzenia. Jednak schowek ten został jednak odnaleziony przez Niemców i rzeczy zaginęły ${ }^{40}$.

\section{Powojenne remonty}

Po powrocie z ewakuacji, w styczniu 1945 roku, przełożona domu zakonnego przy ulicy Wilczej 7, siostra Jadwiga Furmanik przystąpiła do organizacji odbudowy kaplicy. Majster Leopold Zdziarski przy pomocy sióstr pokrył prowizorycznie dach papą i wstawił szyby w oknach ${ }^{41}$. W takim stanie kaplica przetrwała kilka lat.

W 1950 roku, przełożona generalna, matka Wiktoria Bursiak z pomocą architektów: Bolesława Płacheckiego i Konstantego Jakimowicza, przystąpiła do gruntownego remontu kaplicy. Pierwszy remont generalny został zakończony we wrześniu 1950 roku ${ }^{42}$. Był on bardzo kosztowny. Dużej pomocy finansowej na rzecz remontu kaplicy udzielił wówczas mecenas Walerian Strzałkowski, dawny radca prawny „Przytuliska”

\footnotetext{
${ }^{38}$ I. M a lis ze w s k a, S. M a lis ze w s k i, Śródmieście poludniowe: Warszawskie Termopile 1944, Warszawa 2001, s. 114.

${ }^{39}$ Zob. J. K u r s k i, Jan Nowak Jeziorański: Emisariusz wolności, Warszawa 2005, s. 142.

${ }^{40}$ Zob. AFC, sygn. E I, T. I-Kr/3, Kronika kaplicy, s. 31.

${ }^{41}$ Zob. AFC, sygn. E I, T. I-Kr/1, Pierwsza Księga Kroniki Zgromadzenia Sióstr Franciszkanek od Cierpiących prowadzona w Domu Głównym w Warszawie od 1946 roku, s. 5.

${ }^{42}$ Zob. AFC, sygn. E I, T. I-Kr/3, Kronika kaplicy, s. 6.
} 
i przyjaciel zgromadzenia. „Wyczuwając trudności finansowe powziął niezłomną decyzję, oddać na ten cel «resztki», jakie mu pozostały po spieniężeniu jego «ruin bielańskich», ażeby w ten sposób dać dowód swej Niebieskiej Opiekunce, której czci kaplica jest poświęcona, za łaski, [...] które stale uzyskiwał od Boga za Jej pośrednictwem. [...] Resztę życia swego spędził przy świątyni. Każdego dnia służył w kaplicy do Mszy św., w niej odmawiał brewiarz, [...] budując otoczenie wielkim skupieniem i pobożnością,

Po zakończeniu prac remontowych, matka Wiktoria Bursiak zaprosiła księdza prymasa Stefana Wyszyńskiego, aby w odnowionej kaplicy 28 września 1950 roku odprawił mszę św. W przemówieniu, zachęcił siostry, aby w wyremontowanej świątyni stale odnawiały swego ducha, udzielił im też pasterskiego błogosławieństwa ${ }^{44}$.

Po zakończeniu remontu budynku kaplicy, siostry podjęły starania, aby ją jak najlepiej wyposażyć. W 1955 roku, dzięki znajomości z profesorem Feliksem Rączkowskim, organistą kościoła pw. Świętego Krzyża, postawiono na chórze małe organy. Wykonała je firma Biernacki $\mathrm{w}$ porozumieniu $\mathrm{z}$ architektem kaplicy Konstantym Jakimowiczem. W 1956 roku założono w kaplicy instalację nagłaśniającą, którą przeprowadził Tadeusz Michalski, a koszty pokryła Emilia Giersz ${ }^{45}$.

Po zakończeniu soboru watykańskiego II podjęto prace adaptacyjne, by dostosować wnętrze kaplicy do wymagań reformy liturgicznej. Rozpoczęto je w 1970 roku z inicjatywy przełożonej generalnej, matki Władysławy Kuroczyckiej i Zarządu Zgromadzenia. Wówczas w prezbiterium ustawiono nowy ołtarz, tzw. „twarzą do ludu”. Wykonał go stolarz Gierszewski według projektu siostry Mileny Chorembalskiej. Dokonano wymiany przewodów elektrycznych i założono nowe oświetlenie kaplicy. Ściany zostały odnowione przez Świątka. Kolejny remont kaplicy przeprowadzono przed obchodami 100-lecia założenia Zgromadzenia w 1982 roku. Następny gruntowny remont wnętrza i elewacji miał miejsce w 2000 roku. Nadzór nad remontem kaplicy prowadził mgr inż. arch. Ryszard Wyszyński. W lipcu rozpoczęto prace przy elewacji kaplicy i zakrystii. Skuto odpadające tynki, oczyszczono ściany, a następnie nałożono nowe tynki. Pod koniec lipca pomalowano całość elewacji. Prace malarskie wykonała firma Piotra Jasińskiego. We

\footnotetext{
${ }^{43}$ Tamże, s. 7.

${ }^{44}$ Zob. AFC, sygn. E I, T. I-Kr/1, Pierwsza Księga, s. 112.

${ }^{45}$ Zob. tamże, s. 264.
} 
wrześniu ta sama firma wykonała malowanie dachu kaplicy oraz rynien. W październiku na dachu kaplicy założono instalację odgromową.

W październiku 2001 roku kaplicę wyposażono w 21 nowych, dębowych ławek oraz w dwa klęczniki. Do zakrystii wstawiono szafę dębową na ornaty. Prace stolarskie wykonał zakład stolarski należący do Eugeniusza Kułaka. W grudniu tegoż roku zainstalowano witraż Świętego Józefa Kaliskiego w okrągłym oknie prezbiterium kaplicy. Witraż oraz jego montaż wykonała firma Zbigniewa Brzezińskiego z Legnicy.

Ostatnie prace remontowe w kaplicy Matki Bożej Nieustającej Pomocy zostały wykonane w sierpniu 2014 roku. W ramach renowacji pomalowano wnętrze kaplicy i wykonano konieczne prace restauratorskie - poprawiono stan nagłośnienia i oświetlenia, odnowiono żyrandole i kinkiety. Dokonano również koniecznych remontów elewacji.

W lutym 2015 roku wykonano renowację obrazów: św. Józefa oraz św. Elżbiety.

\section{Architektura wnętrza}

Jak już wspomniano, w początkach istnienia zakładu „Przytulisko” kaplica była drewniana. W 1870 roku wybudowano murowaną na jej miejscu, po rozbiórce, w 1913 roku wybudowano nową, większą, istniejącą do dziś.

Kaplica jest murowana, w stosunku do poprzedniej trzykrotnie większa. Nawa ma $13 \mathrm{~m}$ długości i 5,5 m szerokości; prezbiterium - 4,90 m długości, 5 m szerokości; wysokość w nawie wynosi $6,20 \mathrm{~m}$, w prezbiterium - 3,83 m, a w najwyższym punkcie kaplicy sięga 10,05 m. Sklepienie wykonano z żelazobetonu; ma ono charakter żaglowy i krzyżowy. Zarówno sklepienie jak i ściany są pomalowane gładko. Do kaplicy prowadzi jedno wejście. Prezbiterium od nawy głównej oddziela drewniana balustrada. Oratorium i chór muzyczny dzieli drewniana, częściowo zaszklona i rozkładana ściana. Posadzka kaplicy wykonana jest z lastryka.

Urządzeniem kaplicy kierował architekt Konstanty Jakimowicz wraz z matką Kazimierą Gruszczyńską ${ }^{46}$. Wielki ołtarz ustawiono w prezbiterium, według wymagań liturgicznych, na czterech kamiennych słupach połączonych fundamentami. Ołtarz jest drewniany, pomalowany na czarno, zdobiony złoconymi ornamentami. W marmurowej mensie umieszczono relikwie: św. Waleriana, św. Honorata, św. Barbary i jednej

${ }^{46}$ Zob. AFC, sygn. E I, T. I-Kr/3, Kronika kaplicy, s. 3. 
$\mathrm{z}$ towarzyszek św. Urszuli ${ }^{47}$. Tabernakulum wykonane zostało z drewna, wewnątrz złocone złotem dukatowym. Tron dla Najświętszego Sakramentu jest ruchomy, drewniany, złocony, oparty na czterech filarkach. Nastawę wielkiego ołtarza wykonał Borowski.

Na szczycie ołtarza, w owalu, znajduje się obraz św. Elżbiety Węgierskiej, pędzla Zofii Borucińskiej.

We wnęce nastawy ołtarza, na tle marmurowej płyty, umieszczony jest drewniany krucyfiks. Wykonał go Jaworowski. Krucyfiks można zasłonić obrazem św. Józefa, pędzla Kazimierza Mireckiego, albo jednym z trzech innych obrazów: Najświętszego Serca Jezusowego, Matki Boskiej Częstochowskiej, Matki Boskiej z Lourdes.

Na lewej ścianie prezbiterium, na konsoli, znajduje się figura Praskiego Dzieciątka Jezus ${ }^{48}$, ofiarowana do kaplicy przez Bogumiła Skarżyńskiego. Figurka Pana Jezusa wykonana jest z gipsu i mierzy około $60 \mathrm{~cm}$ wysokości. Dzieciątko Jezus jest ubrane w białe, haftowane, królewskie szaty, składające się z sukienki i płaszcza, a na głowie ma królewską koronę. Prawą ręką Dzieciątko błogosławi, w lewej trzyma złote jabłko, będące symbolem władzy królewskiej.

Po prawej stronie prezbiterium, nad wejściem do zakrystii, w okrągłym oknie znajduje się witraż św. Józefa Kaliskiego ${ }^{49}$. Pierwszy witraż wykonany był w pracowni F. Białkowskiego, według wzoru pędzla Michała Borucińskiego. Witraż ufundował Walerian Strzałkowski, radca prawny i przyjaciel „Przytuliska”. W czasie powstania warszawskiego witraż uległ zniszczeniu. W 2001 roku została wykonana jego kopia. Podobnie jak obraz w Kaliszu, witraż przedstawia Świętą Rodzinę, nad którą widnieje postać Boga Ojca, który w dłoni trzyma kulę ziemską. Poniżej widać gołębicę symbolizującą Ducha Świętego. Promienie, wychodzące z Ducha Świętego, padają w dół na postać dwunastoletniego Jezusa, trzymającego za ręce Matkę Bożą i św. Józefa. Pod postaciami Świętej Rodziny rozwinięta jest szarfa ze słowami Idźcie do Józefa. Napis ten przypomina, że Zgromadzenie

\footnotetext{
${ }^{47}$ Zob. tamże, s. 8.

${ }^{48}$ W Pradze, stolicy obecnej Republiki Czeskiej, znajduje się kościół Maryi Panny Zwycięskiej. Kościół należy do karmelitów bosych, a przechowywana jest tam wielka duma Pragi - figurka Małego Króla, jak nazwane jest Praskie Dzieciątko. Zob. S. S k i b a (red.): Mały król; [w:] „, Przymierze z Maryją” 2002, R. II, nr. 7, s. 10-17. ${ }^{49}$ Kolegiata Kaliska jest stolicą kultu św. Józefa w Polsce. Znajduje się tam słynący łaskami i cudami obraz Najświętszej Rodziny.
} 
we wszystkich najważniejszych sprawach oraz trudnościach zawsze szukało i szuka orędownictwa św. Józefa.

W przedniej części nawy kaplicy, po lewej stronie, również na konsoli, umieszczona jest figura św. Franciszka z Asyżu, ofiarowana przez Izabellę Dziekońską.

Nad figurą św. Franciszka z Asyżu, zawieszona jest kopia obrazu Matki Bożej Ostrobramskiej. Obraz pochodzi z głównego ołtarza wileńskiej kaplicy Szpitala Oftalmicznego, gdzie pracowały siostry franciszkanki. Ofiarował go przed I wojną światową ksiądz Wiktor Frąckiewicz. Chorzy, którzy przebywali w szpitalu, niejednokrotnie doznawali łask za wstawiennictwem Matki Bożej, o czym świadczą liczne wota. W czasie II wojny światowej kaplicę zamieniono na salę chorych. Siostry, wyjeżdżając w 1946 roku z Wilna po upaństwowieniu lecznicy, zabrały obraz Matki Bożej Ostrobramskiej ze sobą i umieściły w kaplicy przy ulicy Wilczej $^{50}$. W 2004 roku obraz poddano gruntownej renowacji. W jej zakres weszła konserwacja płótna twarzy i rąk wizerunku Maryi, pozłocenie metalowych fragmentów obrazu, wymiana tkaniny w tle obrazu na nowy czerwony aksamit, wzmocnienie i pozłocenie drewnianej ramy obrazu. Również wota odnowiono i oczyszczono. Koszty renowacji pokryte zostały z ofiar wiernych, uczęszczających do kaplicy.

Matka Kazimiera Gruszczyńska oddała Zgromadzenie Sióstr Franciszkanek od Cierpiących w akcie intronizacji. Również kaplica przy domu generalnym Zgromadzenia została poświęcona Najświętszemu Sercu Jezusowemu. Aktu poświecenia kaplicy dokonał w dniu 10 lipca 1921 roku ojciec Władysław Rejowicz, jezuita. Wówczas w kaplicy zawieszono obraz Serca Jezusowego, pochodzący ze starej kaplicy, gdyż nie było funduszy na nowy, artystyczny ${ }^{51}$. Dopiero w 1952 roku, zawieszono duży, malowany na płótnie obraz Serca Jezusowego pędzla Wawrzyńca Chorembalskiego.

W tylnej części nawy, przy wejściu do kaplicy, po lewej stronie, znajduje figura św. Antoniego, którą ofiarował Jan Sieradzki.

Nad figurą św. Antoniego umieszczony jest obraz św. Teresy od Dzieciątka Jezus, a obok w drewnianej, zaszklonej gablocie dziękczynne wota.

Na ścianach kaplicy, w tylnej jej części, umieszczone są także marmurowe tablice, upamiętniające zmarłych dobroczyńców. Tablica po

${ }^{50}$ Zob. AFC, sygn. E I, T. I-Kr/3, Kronika kaplicy, s. 8-10.
${ }^{51}$ Zob. tamże, s. 25. 
prawej stronie jest poświęcona pamięci hrabiego Bronisława Skarżyńskiego, współzałożyciela „Przytuliska”, zmarłego 2 lutego 1893 roku. Tablicę ufundował zarząd zakładu. Natomiast po lewej stronie wmurowane jest epitafium wraz z popiersiem hrabiego Stanisława Kazimierza Korwina-Kossakowskiego, wieloletniego prezesa zarządu „Przytuliska", zmarłego 17 listopada 1905 roku. Pod tym epitafium znajduje się tablica oraz portret jego zmarłej żony, Michaliny z Zaleskich Kossakowskiej, zmarłej 15 sierpnia 1890 roku w wieku 35 lat.

Przy wejściu do nawy głównej, po prawej stronie znajduje się wejście na chór, na który prowadzą kręte drewniane schody. Balkon chóru zabezpieczony jest drewnianą balustradą. Na chórze w oratorium znajduje się figura św. Józefa. Matce Kazimierze Gruszczyńskiej bardzo zależało na umieszczeniu tej figury w kaplicy, gdyż tworzone przez siebie Zgromadzenie Sióstr Franciszkanek od Cierpiących powierzyła szczególnej opiece św. Józefa. Ciekawą historię figury przedstawia notatka zamieszczona w Kronice kaplicy: „W 1882 roku zdarzył się w Warszawie dziwny przypadek. Ulicą Wilczą przejeżdżała hrabina Stanisławowa Łubieńska. Przed „Przytuliskiem” złamało się koło u powozu. Hrabina $\mathrm{z}$ potłuczoną nogą musiała zatrzymać się przez parę godzin w Zakładzie. Matka Kazimiera, rozmawiając z gościem o różnych sprawach, powiedziała też, iż pragnie umieścić na dziedzińcu statuę św. Józefa, ale z braku funduszy zostanie to tylko marzeniem. Hrabina słuchała $z$ wielkim zainteresowaniem i uśmiechając się, rzekła: mam bardzo ładną figurę św. Józefa nadającą się na ten cel i chętnie mogę ofiarować. Matka Kazimiera wzruszona była tym dowodem Opatrzności Bożej. W niedługim czasie po tym wydarzeniu, nadeszło zawiadomienie odbioru przesyłki, w której była figura św. Józefa. Podczas poświęcenia nowej kaplicy w 1915 roku umieszczono na przylegającym do niej dziedzińcu spiżową kopię tej figury, sporządzoną przez firmę «Bracia Łopieńscy»" ${ }^{52}$.

W tzw. „bramie” - przedsionku kaplicy, znajduje się trzecia figura św. Józefa. Pochodzi ona z tarasu szpitala - „Sanatorium św. Józefa" przy ulicy Emilii Plater 18. Szpital ten, wybudowany z inicjatywy i dzięki staraniu Założycielki w 1910 roku, do 1949 roku, kiedy to został upaństwowiony, był własnością Zgromadzenia Sióstr Francisz-

${ }^{52}$ Tamże, s. 34-35. 
kanek od Cierpiących. W 1951 roku dyrekcja placówki odesłała figurę do domu sióstr na ulicę Wilczą $7^{53}$.

W przedsionku kaplicy, po obydwu stronach drzwi wejściowych do nawy głównej, znajdują się dwie tablice, poświęcone pamięci Matki Kazimiery Gruszczyńskiej oraz bł. Honorata Koźmińskiego.

Nieco dalej, po lewej stronie, wmurowana jest tablica ku pamięci Zofii Kurmanowej, założycielki i przełożonej Warszawskiej Pensji Żeńskiej oraz Lucyny Kalinowskiej, dyrektorki szkoły.

We wrześniu 2005 roku odbyło się uroczyste wmurowanie tablicy ku pamięci porucznika Zdzisława Jeziorańskiego ps. Jan Nowak.

\section{Obraz Matki Bożej Nieustającej Pomocy}

W kaplicy, w nawie głównej, w bocznym ołtarzu z 1891 roku, znajduje się obraz Matki Bożej Nieustającej Pomocy, głównej patronki świątyni ${ }^{54}$. Wizerunek okala czternaście złotych róż oraz wota w kształcie serc, umieszczone na bogato zdobionej ramie. Obraz jest wierną kopią cudownej ikony Matki Bożej Nieustającej Pomocy ${ }^{55}$ z kościoła ojców redemptorystów w Rzymie. Namalowany jest na desce z drewna cyprysowego o wymiarach $53 \times 41,5 \mathrm{~cm}$, zgodnie z parametrami autentycznego obrazu ${ }^{56}$.

Historia obrazu Matki Bożej Nieustającej Pomocy jest ściśle związana z historią Zgromadzenia Sióstr Franciszkanek od Cierpiących, które zawsze doświadczało opieki Bożej przez wstawiennictwo Maryi. Kopię obrazu, potwierdzoną dokumentem z dnia 15 stycznia 1889 roku i oznaczoną $\mathrm{nr} 1266^{57}$, sprowadziła z Rzymu do Warszawy w roku 1889 Kazimiera Gruszczyńska. Podczas prywatnej audiencji

\footnotetext{
${ }^{53}$ Zob. tamże, s. 35-36.

${ }^{54}$ Według tradycji ikona Matki Bożej Nieustającej Pomocy zawdzięcza swój tytuł objawieniu, które otrzymała pewna rzymianka we śnie, gdy obraz ten znajdował się w jednym z rzymskim domów. Matka Najświętsza żądała, aby obraz został umieszczony w kościele. Wtedy też objawiła swe imię: Matka Nieustającej Pomocy. Zob. M. Kot yń s ki, Medytacje nad Ikona Matki Bożej Nieustającej Pomocy, Kraków 2006, s. 78.

${ }_{55}$ Zob. M. K o t yń s k i, Medytacje nad Ikoną, s. 62

${ }^{56}$ Zob. A. Ła bu d a, Ikona Matki Bożej Nieustającej Pomocy w Mościskach, Lublin 2001, s. 23.

${ }^{57}$ Każda kopia oznaczona była własnym numerem. Numer ten umożliwiał dokładną ewidencję wysyłanych egzemplarzy. Do obrazu dołączane były odpusty związane z jego kultem. Zob. tamże.
} 
udzielonej Matce Gruszczyńskiej papież Leon XIII poświęcił obraz i nałożył liczne odpusty, związane z jego czcią.

Ksiądz biskup Kazimierz Ruszkiewicz uroczyście intronizował obraz w kaplicy „Przytuliska” w dniu 31 grudnia 1891 roku. Jako wyraz wdzięczności za zatwierdzenie Zgromadzenia Sióstr Franciszkanek od Cierpiących przez Stolicę Apostolską, Matka Kazimiera Gruszczyńska ufundowała koronę ,z kosztownymi kamieniami, sporządzoną z biżuterii, którą siostry złożyły w posagu" "58. Koronacji obrazu Matki Bożej Nieustającej Pomocy dokonał ksiądz kardynał Aleksander Kakowski 27 czerwca 1924 roku. W Kronice kaplicy czytamy: „Najdostojniejszy Arcypasterz odprawił w kaplicy przed wielkim ołtarzem Mszę św. [...] poczem procesjonalnie udał się przed Ołtarz Matki Boskiej Nieustającej Pomocy, gdzie przygotowana była cenna korona. Na poduszce trzymały ją dzieci architekta Jakimowicza, Kasia i Zygmuś. Po poświęceniu Eminencja własnoręcznie włożył koronę na skronie Matki Najśw. i Boskiego Jej Dzieciątka"59.

Obraz był od początku otaczany wielką czcią. Ma on zasłonę, którą stanowi obraz św. Franciszka z Asyżu, namalowany na płótnie przez artystę Kazimierza Mireckiego. Obraz był odsłaniany w soboty przy śpiewie hymnu:

\section{Matko Boska Nieustającej Pomocy Matko Laskawa o jak w tym obrazie zawsze stynie stawa żeś nam wszystkim obrona. Zachowaj nas od głodu, powietrza $i$ wojny daj nam tu na ziemi zawsze czas spokojny bąź nam wszystkim obrona.}

Msza św. w soboty zawsze była odprawiana przed cudownym obrazem Matki Bożej Nieustającej Pomocy. Obecnie w każdą środę odprawiane jest nabożeństwo Nieustannej Nowenny, którego celem jest rozbudzanie i podtrzymywanie praktyki ciągłej modlitwy. Do tego nabożeństwa należy: Modlitwa rzymska, rozważanie słowa Bożego, pieśni maryjne. W czasie nowenny odczytywane są podziękowania i prośby przedstawione przez uczestników. Widocznym znakiem łask

\footnotetext{
${ }^{58}$ Zob. AFC, sygn. E I, T. I-Kr/3, Kronika kaplicy, s. 10.

59 Tamże, s. 14.
} 
otrzymywanych za pośrednictwem Matki Bożej Nieustającej Pomocy są liczne wota, umieszczone $\mathrm{w}$ gablotach przy obrazie. Wiele dawnych wotów zginęło w czasie powstania i ewakuacji Warszawy w 1944 roku $^{60}$.

\section{8. Życie religijne}

Matka Założycielka była świadoma doniosłości znaczenia świątyni w życiu każdego człowieka, a przede wszystkim w życiu sióstr. Wiedziała, że kaplica jest miejscem, gdzie ogniskuje się życie wspólnoty zakonnej. Tutaj zbiera się ona na Eucharystii, modlitwie, nabożeństwach, tutaj kształtuje się jej życie duchowe. Dlatego też, od samego początku, istnienie kaplicy w domu zakonnym miało dla Matki fundamentalne znaczenie ${ }^{61}$.

Kazimiera Gruszczyńska była głęboko przywiązana do polskiej pobożności. Od chwili przybycia do „Przytuliska” chciała, aby w kaplicy były odprawiane nabożeństwa wyrażające typowo polską tradycję religijną: pasterka, rezurekcja, procesja eucharystyczna w uroczystość Bożego Ciała. Dzięki staraniom Założycielki wprowadzono w kaplicy także nabożeństwa majowe, gorzkie żale, drogę krzyżową oraz nieszpory w języku polskim ${ }^{62}$.

W kaplicy od początku istnienia bardzo uroczyście obchodzi się uroczystości i święta Zgromadzenia, związane z jego duchowością. Głównym patronem Zgromadzenia Sióstr Franciszkanek od Cierpiących jest św. Józef, dlatego szczególnie podniosły charakter mają obchody jego uroczystości 19 marca, a w środy, o ile pozwalają na to przepisy liturgiczne, odprawiana jest wotywa ku jego czci. Ze względu na duchowość franciszkańską, uroczyście obchodzone jest święto św. Franciszka z Asyżu - 4 października, święto stygmatów św. Franciszka - 17 września, św. Elżbiety Węgierskiej - 17 listopada. Bardzo uroczyście obchodzi się także rocznicę założenia Zgromadzenia, która przypada w dniu 26 kwietnia, oraz święta i wspomnienia związane z życiem i działalnością założycieli: bł. Honorata Koźmińskiego i sł. Bożej Kazimiery Gruszczyńskiej.

Od początku istnienia, kaplica Matki Bożej Nieustającej Pomocy miała zapewnioną stałą opiekę duszpasterską. Sprawowali ją kapelani

\footnotetext{
${ }^{60}$ Zob. tamże, s. 11.

${ }^{61}$ Zob. K. G r u s z c z y ń s k a, Historia Zgromadzenia, s. 37.

${ }^{62}$ Zob. AFC, sygn C I, T. II-MK/67, H. Wł a d z i ń s k a, Wspomnienia, s. 52-53.
} 
wyznaczani przez Kurię Metropolitalną Warszawską. Pierwszymi kapelanami byli warszawscy kapucyni: najpierw ojciec Fidelis Paszkowski, a później ojciec Alberyk Gerban. Gdy Kazimiera Gruszczyńska obejmowała funkcję przełożonej „Przytuliska”, duszpasterstwo w kaplicy sprawował ksiądz archidiecezji warszawskiej, Mateusz Żarnicki. Po nim został kapelanem na wiele lat ksiądz Piotr Busiakiewicz. W kronice wymienione są też nazwiska księży: Karola Polikowskiego, Aleksandra Fajęckiego, Antoniego Świętochowskiego, Bronisława Kolasińskiego, Franciszka Toporskiego, Antoniego Kwiecińskiego i in. ${ }^{63}$. Od 1973 roku funkcję kapelana w kaplicy przy ulicy Wilczej 7, pełnią księża pallotyni. Dotychczas byli to: Edward Winklarz, Józef Dąbrowski, Marian Sobczyk, Sławomir Zaręba, Zbigniew Babicki, Stanisław Janik, Eugeniusz Klimiński, Jerzy Błaszczak. Obecnie, kapelanem w kaplicy Matki Bożej Nieustającej Pomocy jest ksiądz Grzegorz Kalbarczyk ${ }^{64}$.

Ważną rolę w przeżywaniu liturgii i nabożeństw spełnia muzyka i śpiew. Od początku istnienia kaplicy, mszę świętą i nabożeństwa uświetniała gra na fisharmonii. Od 1900 roku, ze Zgromadzeniem Sióstr Franciszkanek od Cierpiących związany był słynny organista i kompozytor utworów religijnych - Józef Furmanik, ojciec sióstr: Julii i Jadwigi, znany też jako profesor szkoły organistowskiej oraz organista kościoła św. Aleksandra w Warszawie. Dzięki niemu, w uroczystość Ofiarowania Matki Boskiej w 1909 roku, siostry po raz pierwszy wykonały nieszpory liturgiczne w języku łacińskim. Pod jego dyrekcją śpiewały Jutrznię na Boże Narodzenie i Wielkanoc. Podczas większych świąt i uroczystości akompaniował siostrom i sam grał w kaplicy, bezinteresownie uczył siostry gry na fisharmonii.

W latach 1912-1946 organistką w kaplicy na Wilczej była siostra Jadwiga Furmanik (córka Józefa Furmanika), a od 1946 roku funkcję tę pełniła siostra Franciszka Stępniak. W historii Zgromadzenia zapisane są także siostry o wybitnych głosach, jak siostra Ewelina Kalinowska (siostra profesora Władysława Kalinowskiego, organisty katedry wileńskiej), śpiewająca altem, siostra Marta Sawukinas, śpiewająca sopranem $^{65}$, jak też siostry: Antonina Chobotko, Wanda Olborska, Janina Mularczyk, Irena Młodziejko.

\footnotetext{
${ }^{63}$ Zob. tamże s. $18-19$.

${ }^{64}$ Zob. AFC, sygn. E I, T. I-Kr/3, Kronika kaplicy, s. 50.

${ }^{65}$ Zob. tamże, s. 29.
} 
Podsumowując należy podkreślić, że od początku istnienia kaplica Matki Bożej Nieustającej Pomocy była i jest miejscem, gdzie przeplatają się ze sobą przeżycia religijne, patriotyczne i społeczne. Tutaj ludność Warszawy wraz z siostrami gromadzi się na modlitwie osobistej, na przeżywaniu dorocznych świąt kościelnych i uroczystości religijnych. Omodlane są także sprawy ojczyzny - w czasie niewoli i zawieruchy wojennej wypraszano dla niej wolność, składano dziękczynienie po oswobodzeniu z okupacji, a teraz obchodzone są rocznice tych wydarzeń. Obecnie także miejsce to jest otwarte dla wszystkich, którzy pragną w nim doświadczyć spotkania z Bogiem, ale także $\mathrm{z}$ historią zamkniętą w murach tego kościoła.

\section{Bibliografia}

\section{Źródła archiwalne}

Archiwum Zgromadzenia Sióstr Franciszkanek od Cierpiących w Warszawie (AFC)

- sygn. D I, T. VII-Przyt/30, Akta Budowy Kaplicy w Przytulisku w Warszawie 1913.

- sygn. E I, T. I-oD/3, Czerwińska B., Powstanie sierpniowe 1944 r. - warszawskie notatki Barbary Czerwińskiej 1 VIII-30 IX 1944 r.

- sygn. D I, T. VI-Przyt/8, Dokumenty konsekracji kaplicy i dzwonu.

- sygn. E I, T. I-oD/34, Grajewska M., Fragmenty przeżyć i myśli z powstania 1944 r. - dziennik Małgorzaty Grajewskiej prowadzony od 1 VIII-1 IX 1944 r.

- sygn. D I, T. VI-Przyt/15, Kaplica Instytutu Dobroczynnego przy ulicy Wilczej 7.

- sygn. E I, T. II-Kr/12, Kronika Domu Generalnego w Warszawie.

- sygn. E I, T. I-Kr/3, Kronika kaplicy Przytuliska.

- sygn. E I, T. I-Kr/1, Pierwsza Księga Kroniki Zgromadzenia Sióstr Franciszkanek od Cierpiących prowadzona w Domu Głównym w Warszawie od 1946 roku.

- sygn. D I, T. VII-Przyt/28, Rachunki kaplicy Przytuliska [dochody i rozchody].

- sygn. C I, T. II-MK/67 Władzińska H., Wspomnienia.

- sygn. D I, T. VI-Przyt/9, Z chwili poświęcenia kamienia węgielnego pod kaplicę Przytuliska.

\section{Źródła drukowane}

Gruszczyńska K., Historia Zgromadzenia S.S. Franciszkanek od Cierpiacych, oprac. L. Czermińska, J. Marecki, Kraków 2019. 


\section{Opracowania}

„Kurier Warszawski”, 10 czerwca 1913, nr 158.

Ekner J., KAPLICA p. w. Matki Bożej Nieustającej Pomocy. [Artykuł w zbiorach prywatnych Autora].

Gruszczyńska K., Historia Zgromadzenia S.S. Franciszkanek od Cierpiących, oprac. L. Czermińska, J. Marecki, Kraków 2019.

Kotyński M., Medytacje nad Ikona Matki Bożej Nieustającej Pomocy, Kraków 2006.

Kurski J., Jan Nowak Jeziorański: Emisariusz wolności, Warszawa 2005.

Łabuda A., Ikona Matki Bożej Nieustającej Pomocy w Mościskach, Lublin 2001. Maliszewska I., Maliszewski S., Śródmieście potudniowe: Warszawskie Termopile 1944, Warszawa 2001.

Skiba S. (red.), Mały król, [w:] „Przymierze z Maryja” 2002, R. II, nr 7.

\section{MARIA KORNAŚ CSFA LUCYNA CZERMIŃSKA CSFA}

\section{HISTORIA KAPLICY POD WEZWANIEM MATKI BOŻEJ NIEUSTAJĄCEJ POMOCY PRZY UL. WILCZEJ W WARSZAWIE}

Streszczenie: Historia Kościoła ściśle łączy się z historią narodu. Kościół katolicki w Polsce odgrywał dużą rolę w jej dziejach. Dzieje kaplicy Matki Bożej Nieustającej Pomocy oraz środowiska ludzi, którzy byli i są z nią związani, pisane były na wspólnej karcie dziejów Warszawy. Kaplica od początku swojego istnienia związana była z „Przytuliskiem”, instytucją dobroczynną powstałą, na terenie Warszawy. Szeroka działalność dobroczynna w II połowie XIX wieku była odpowiedzią na problemy ubogiego świata pracy oraz narastającą biedę. To właśnie „Przytulisko” stało się fundamentem tworzącego się Zgromadzenia Sióstr Franciszkanek od Cierpiących, a kaplica stała się własnością sióstr. Pierwsza kaplica powstała w roku 1856 i była kaplicą przenośną. Stałą kaplicę - początkowo drewnianą wzniesiono w miejscu stałej siedziby „Przytuliska” w 1870, w niedługim czasie powstała kaplica murowana. Ze względu na znaczne zniszczenie, kaplicę trzeba było przebudować. W obecnej formie istnieje od roku 1915. Mimo działań wojskowych i zniszczeń, jakie dotknęły Warszawę w latach II wojny światowej, kaplica Matki Bożej Nieustającej Pomocy mimo znacznych uszkodzeń, nie została całkowicie zburzona. Po przeprowadzeniu koniecznych remontów, służy nieprzerwanie siostrom franciszkankom od cierpiących, a także mieszkańcom stolicy, którzy do niej uczęszczają. W kaplicy, oprócz licznych figur, obrazów, znajduje się ołtarz poświęcony głównej patronce - Matce Bożej Nieustającej Pomocy z kopią jej ikony. Przywieziony został z Rzymu przez Kazimierę Gruszczyńska, założycielkę Zgromadzenia Sióstr Franciszkanek od Cierpiących. O czci, jaką Matka Bożą odbiera w tej świątyni, świadczą liczne wota zgromadzone 
w gablotach zawieszonych na ścianach obok ołtarza. Epitafia i tablice pamiątkowe zamieszczone na ścianach kaplicy i w jej przedsionku, wskazują, że w tym miejscu przeplatają się ze sobą dzieje narodu, kościoła oraz doświadczenie religijne wielu osób.

Slowa klucze: Przytulisko, kaplica Matki Bożej Nieustającej Pomocy, życie religijne, Kazimiera Gruszczyńska.

\title{
THE HISTORY OF THE CHAPEL OF OUR LADY OF PERPETUAL HELP AT WILCZA STREET IN WARSAW
}

\begin{abstract}
The history of the Church is closely related to the history of the nation. The Catholic Church in Poland played a large role in its history. The history of the Chapel of Our Lady of Perpetual Help and the circle of people who were and are connected with it were closely woven with the history of Warsaw. From the beginning, the chapel was associated with "the Shelter" (Przytulisko), a charitable institution founded in Warsaw. Broad charity activity in the second half of the $19^{\text {th }}$ century was a response to the problems of the poor world of work and growing poverty. It was "the Shelter" that became the foundation of the Congregation of the Franciscan Sisters of Suffering, and the chapel became the property of the Sisters. The first chapel was founded in 1856 and was a transitory chapel. The permanent chapel - initially wooden - was erected in the place of the permanent seat of "the Shelter" in 1870, and soon a brick chapel was built. Due to significant destruction, the chapel had to be rebuilt. In its present form, it has existed since 1915. Despite the military activities and destruction that affected Warsaw in the years of World War II, the Chapel of Our Lady of Perpetual Help - despite considerable damage, was not completely demolished. After carrying out the necessary repairs, it has continuously served the Franciscan Sisters as well as the inhabitants of the capital who attend it. In the chapel, apart from many statues and paintings, there is an altar dedicated to the Main Patron - Our Lady of Perpetual Help with a copy of her icon. The altar was brought from Rome by Kazimiera Gruszczyńska, the founder of the Congregation of the Franciscan Sisters of Suffering. The veneration which Our Lady receives in the chapel is evidenced by the numerous votive offerings in the display cases hung on the walls next to the altar. Epitaphs and commemorative plaques placed on the walls of the chapel and in its vestibule indicate that the history of the nation, the church and the religious experience of many people are intertwined in this place.
\end{abstract}

Keywords: "The Shelter" (Przytulisko), the Chapel of Our Lady of Perpetual Help, religious life, Kazimiera Gruszczyńska. 